\title{
Sulfentrazone Selectivity and Efficiency in Cassava Crops in SANDY AND Clayey SoIls ${ }^{1}$
}

\author{
Seletividade e Eficiência do Sulfentrazone em Cultivos de Mandioca em Solo Arenoso e Argiloso
}

COSTA, N.V. ${ }^{2}$, FERREIRA, S.D. ${ }^{2}$, RAMELLA, J.R. ${ }^{2}$, MORATELLI, G. ${ }^{2}$, and DOURADO, R.F. ${ }^{2}$

\begin{abstract}
Weeds have the potential to dramatically interfere in cassava cultivation, reducing its productive potential; however, there are few studies on the selective herbicides in this crop. Therefore, the objective was to evaluate in this work the selectivity and efficiency of sulfentrazone in cassava crops grown in sandy and clayey soils. Two experiments were carried out: The first one was carried out in sandy soil conditions in the conventional system; and the second one was carried out in clayey soil conditions in the no-tillage system. The experimental design was a randomized block with four replications. The treatments consisted in doses of 250, 500, 750 and 1,000 $\mathrm{g} \mathrm{ha}^{-1}$ of sulfentrazone, and weeded and non-weeded controls. Sulfentrazone application in cassava crops has linearly reduced the production of roots in a proportion of 0.0153 and $0.0107 \mathrm{t} \mathrm{ha}^{-1}$ at each increment in grams of the active ingredient, respectively. It was concluded that sulfentrazone was not selective for cassava crops grown both in sandy and in clayey soil; however, it was highly effective in weed control in both soils.
\end{abstract}

Keywords: chemical control, Protox inhibitors, weed, Manihot esculenta.

RESUMO - As plantas daninhas têm o potencial de interferir drasticamente no cultivo da mandioca, diminuindo o seu potencial produtivo, porém, ainda são poucos os estudos sobre os herbicidas seletivos nessa cultura. Objetivou-se avaliar, neste trabalho, a seletividade e a eficiência do sulfentrazone na cultura da mandioca cultivada em solos arenoso e argiloso. Foram implantados dois experimentos: o primeiro foi instalado em condição de solo arenoso, no sistema convencional; e o segundo, em condição de solo argiloso, no sistema de plantio direto. $O$ delineamento experimental utilizado foi o de blocos ao acaso com quatro repetições. Os tratamentos consistiram nas doses de 250, 500,750 e $1.000 \mathrm{~g} \mathrm{ha}^{-1}$ do sulfentrazone, além de uma testemunha capinada e outra não capinada. A aplicação do sulfentrazone nos cultivos de mandioca reduziu de forma linear a produção de raizes, numa proporção de 0,0153 e 0,0107 tha-1 a cada incremento em gramas do ingrediente ativo, no solo arenoso e argiloso, respectivamente. Concluiu-se que o sulfentrazone não foi seletivo para a cultura da mandioca cultivada tanto em solo arenoso quanto em solo argiloso, entretanto, foi altamente eficiente no controle das plantas daninhas em ambos os solos.

Palavras-chave: controle químico, inibidor da Protox, planta daninha, Manihot esculenta.

Recebido para publicação em 16.7.2015 e aprovado em 25.8.2015.

Universidade Estadual do Oeste do Paraná (Unioeste), Marechal Cândido Rondon, PR, Brasil, <neumarcio.costa@unioeste.br>. 


\section{INTRODUCTION}

Cassava cultivation in Brazil can be held in all regions, which shows the species high hardiness and adaptability to different soil and climate types (Cuenca \& Mandarino, 2006). Among the major producing regions, Paraná State has stood out in the 2014/2015 season as the second largest producer of cassava, with an acreage around 177.1 thousand ha $^{-1}$ and production of 4.0 million tons of roots, with an average yield of $23.0 \mathrm{t} \mathrm{ha}^{-1}$, equivalent to $17.5 \%$ of the national production (IBGE, 2015). However, most of the Paraná cassava production is intended for the starch and flour industries.

Whereas the cassava cycle can range 8-24 months or so, depending on the purpose, the crop is subject to the weed community interference, which is favored by the slow initial growth and the wide spacing of the rows used in the cassava cultivation (Azevêdo et al., 2000; Peressin \& Carvalho, 2002; Silva et al., 2012).

Thus, it is essential to perform the weed community control, since weed competition can retard the cassava plants growth and development, and reduce size, weight and number of roots within 90\% (Johanns \& Contiero, 2006; Albuquerque et al., 2008).

Optionally, the chemical method of weed control is characterized by allowing intervention in large areas with little labor dependency and quick application (Biffe et al., 2010). However, cassava response to herbicides application may vary from total selectivity for some products until full production jeopardy because of crop poisoning (Silveira et al., 2012; Costa et al., 2013).

Since cassava is a culture that has no great impact on the national productive scenario compared to cultures of greater expression, such as soybeans, maize and sugarcane, there is great interest from pesticide companies in registering their products for this culture (Silva et al., 2009). Moreover, there are few studies on weeds control methods involving selective herbicides for cassava cultivation, especially for use in crop preemergence.

In Brazil there are only six active ingredients of herbicides that are registered for cassava crops, spread over four mechanisms of action: ametryn and metribuzin (photosystem II); clethodim (AcCase); clomazone and isoxaflutole (carotenoid biosynthesis); and trifluralin (microtubule formation inhibitor) (Rodrigues \& Almeida, 2011). This small number of herbicides and mechanisms of action may hinder the development of tillage strategies, in addition to providing increased resistant biotypes selection pressure (Beckie, 2006; Beckie \& Reboud, 2009; Vencill et al., 2012).

Thus, sulfentrazone emerges as an option for weed control in cassava crops because of the high efficiency and the fact that the mechanism of action (Protox) is different from the herbicides registered (El-Sharkawy, 2004; Silva et al., 2009; Scariot et al., 2013). However, sulfentrazone has shown low selectivity to cassava plants when grown in sandy soil (Oliveira Jr. et al., 2001).

Therefore, this study hypotheses are based on the fact that sulfentrazone selectivity in cassava plants can be dependent on dose and type of cultivated soil. Thus, this study aimed to evaluate sulfentrazone selectivity and efficiency in cassava crops grown in sandy and clayey soils.

\section{MATERIALS AND METHODS}

Two experiments in cassava production areas were established and conducted in the western region of the Brazilian state of Paraná.

The first experiment was conducted in sandy soil conditions in the municipality of Francisco Alves, PR, in a site located at $24^{\circ} 03^{\prime} 57^{\prime \prime}$ S latitude and $54^{\circ} 50^{\prime} 52^{\prime \prime} \mathrm{W}$ longitude, in the conventional soil management system, with one plowing and two harrowings. The planting of cassava cultivar "Olho Junto" was done on $10 / 15 / 2012$, with the aid of a mechanical planter, spaced $0.85 \times 0.50 \mathrm{~m}$.

Chemical analysis of the soil had the following characteristics: $\mathrm{pH}\left(\mathrm{CaCl}_{2}\right)=5.1$; organic matter $\left(\mathrm{g} \mathrm{dm}^{-3}\right)=15.0 ; \mathrm{P}\left(\mathrm{mg} \mathrm{dm}^{-3}\right)$ $=3.6 ; \mathrm{H}+\mathrm{Al}, \mathrm{K}, \mathrm{Ca}, \mathrm{Mg}, \mathrm{SB}$ and CTC $\left(\mathrm{cmol}_{\mathrm{c}} \mathrm{dm}^{-3}\right)$ $=3.46 ; 0.29 ; 2.00 ; 0.41 ; 2.70$ and 6.16 , respectively; and $\mathrm{V} \%=43.83$, having in its textural composition $71.6 \%$ of sand, $7.2 \%$ of 
silt and $21.2 \%$ of clay. The crop was not fertilized.

The treatments applications were done three days after planting (10/18/2012) and at the application time the cuttings showed no buds with budding. A knapsack sprayer was used, pressurized at $\mathrm{CO}_{2}$ and fitted with a plane jet six-nozzle broom (model Magno ADGA 11002), spaced by $50 \mathrm{~cm}$, with a spray mix consumption equivalent to $200 \mathrm{~L} \mathrm{ha}^{-1}$, using pressure of $4.3 \mathrm{kgf} \mathrm{cm}^{-2}$.

Applications were done in moist soil condition and in the morning (9.30am to $10 \mathrm{am})$, with the following conditions of temperature, relative humidity and wind speed, respectively: $24.4{ }^{\circ} \mathrm{C}, 55 \%$ and $5.4 \mathrm{~km} \mathrm{~h}^{-1}$.

Evaluations were carried out at 25, 32, 39 and 55 days after herbicide application (DAA).

At harvest of the cassava roots in the first experiment $(06 / 12 / 2013)$, the plants were collected from two central rows of the plots, disregarding a plant from each end of the rows as border. After weighing the roots, productivity was determined $\left(\mathrm{t} \mathrm{ha}^{-1}\right)$. A sample of $5.0 \mathrm{~kg}$ of roots was collected from each plot to determine the percentage of starch, using the hydrostatic balance method, as proposed by Grossmann \& Freitas (1950).

The second experiment was carried out in clayey soil conditions in the district of Porto Mendes, PR, belonging to the municipality of Marechal Cândido Rondon, PR, located

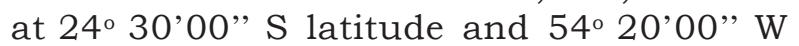
longitude, in the direct seeding system. The planting of cassava cultivar "Baianinha" was done on $09 / 21 / 2013$, with the aid of a mechanical planter adapted to the direct seeding, spaced $0.90 \times 0.65 \mathrm{~m}$.

Chemical analysis of the soil had the following characteristics: $\mathrm{pH}\left(\mathrm{CaCl}_{2}\right)=5.3$; organic matter $\left(\mathrm{g} \mathrm{dm}^{-3}\right)=22.6 ; \mathrm{P}\left(\mathrm{mg} \mathrm{dm}^{-3}\right)$ $=6.92 ; \mathrm{H}+\mathrm{A} 1, \mathrm{~K}, \mathrm{Ca}, \mathrm{Mg}, \mathrm{SB}$ and $\mathrm{CTC}$ $\left(\mathrm{cmol}_{\mathrm{c}} \mathrm{dm}^{-3}\right)=3.36 ; 0.75 ; 6.56 ; 0.74 ; 8.05$ and 11.41 , respectively; and $\mathrm{V} \%=70.55$, having in its textural composition $9.8 \%$ of sand, $35.7 \%$ of silt and $54.5 \%$ of clay. The culture was fertilized at the base with $350 \mathrm{~kg} \mathrm{ha}^{-1}$ of formulation NPK/0-15-19.
The experimental design was a randomized block with four replications. The treatments consisted in doses of 250, 500, 750 and $1,000 \mathrm{~g} \mathrm{ha}^{-1}$ of sulfentrazone (Boral $500 \mathrm{SC}-$ $\left.500 \mathrm{~g} \mathrm{~L}^{-1}\right)$, plus weeded and non-weeded controls for both experiments.

The plots consisted in four rows of cassava spaced $0.90 \mathrm{~m}$, being $5.0 \mathrm{~m}$ long, totaling $18.0 \mathrm{~m}^{2}$; the floor area corresponded to $6.66 \mathrm{~m}^{2}$.

The treatments applications were done four days after planting (09/25/2013) and at the application time the cuttings showed no buds with budding. A knapsack sprayer was used, pressurized at $\mathrm{CO}_{2}$ and fitted with a plane jet six-nozzle broom (model Teejet TT 1002), spaced by $50 \mathrm{~cm}$, with a spray mix consumption equivalent to $200 \mathrm{~L} \mathrm{ha}^{-1}$, using pressure of $3.0 \mathrm{kgf} \mathrm{cm}^{-2}$.

Applications were done in moist soil condition and in the afternoon $(3.10 \mathrm{pm}$ to $3.25 \mathrm{pm})$, with the following conditions of temperature, relative humidity and wind speed, respectively: $21.8{ }^{\circ} \mathrm{C}, 50 \%$ and $4.1 \mathrm{~km} \mathrm{~h}^{-1}$.

The evaluations were performed at 23, 36, 41, 56 and 70 DAA.

During roots collection of the second experiment $(07 / 05 / 2014)$, the plants were collected from two central rows of the plots, disregarding a plant from each end of the rows as border. After weighing the roots, productivity was determined $\left(\mathrm{t} \mathrm{ha}^{-1}\right)$. A sample of $5.0 \mathrm{~kg}$ of roots was collected from each plot to determine the percentage of starch, using the hydrostatic balance method, as proposed by Grossmann \& Freitas (1950).

The assessments of cassava plants intoxication and weed control were done visually, using a scale of percentage grades, where 0 (zero) corresponds to no injury demonstrated by the cassava plant and 100 (one hundred) to the death of the cassava plants (SBCPD, 1995). The criteria used to establish the grades were: growth inhibition, amount and uniformity of injuries, regrowth capacity of plants and quantity of dead plants.

The results were submitted to analysis of variance by $\mathrm{F}$-test at $5 \%$ probability, and the 
means were subjected to regression analysis with the chosen equations, considering the significance of the F-test, the normality and the high coefficient of determination $\left(R^{2}\right)$.

\section{RESULTS AND DISCUSSION}

In Figure 1A can be seen mild symptoms of intoxication $(\leq 20 \%)$ in cassava plants after application of $250 \mathrm{~g} \mathrm{ha}^{-1}$ of sulfentrazone in the evaluation period, but the doses of $500 \mathrm{~g} \mathrm{ha}^{-1}$ promoted symptoms considered moderate $(\leq 40 \%)$. The doses of 750 and $1,000 \mathrm{~g} \mathrm{ha}^{-1}$ of sulfentrazone caused severe symptoms $(\geq 60 \%)$ at the end of the evaluations (53 DAA) in sandy soil. In Figure 1B, it was observed that doses of up to $750 \mathrm{~g} \mathrm{ha}^{-1}$ of sulfentrazone have caused intoxication symptoms considered mild

(A)

$\hat{y}=40.6609+0.0989$ Dose-1.9585DAA-4.7857E-06Dose ${ }^{2}+0.0186 D_{A A}^{2} ; R^{2}=0.93^{* *}$

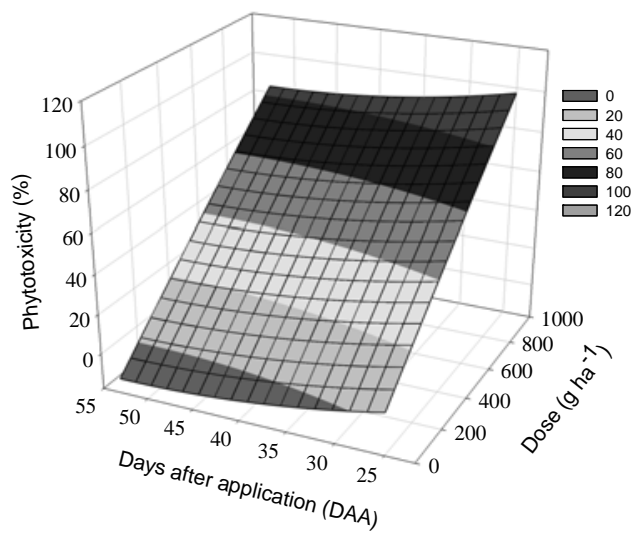

(B)

$\hat{y}=67.6477 \exp \left(-0.5\left(\left((\text { Dose-1298.4633)/415.4414) })^{2}+\left((\text { DAA-48.3032) } / 14.1839)^{2}\right)\right) ; R^{2}=0.86^{\star \star}\right.\right.$

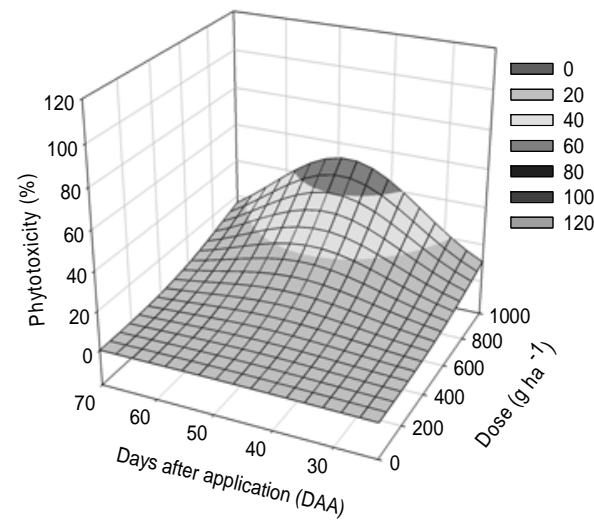

** significant at $1 \%$ by F-test.

Figure 1 - Phytotoxicity percentage in cassava plants after applying sulfentrazone in sandy (A) and clayey (B) soils. $(\leq 20 \%)$ in cassava plants; however, doses above $750 \mathrm{~g} \mathrm{ha}^{-1}$ of sulfentrazone have caused moderate symptoms $(\leq 60 \%)$, and the symptoms were visible from 35 to 65 DAA in the clayey soil.

In Figure 2, weeds control percentages after application of sulfentrazone in sandy (Figure 2A) and clayey (Figure 2B) soils can be seen. The weed control provided by sulfentrazone in both soils was considered excellent ( $\geq 80 \%$ ) for a period of up to 55 DAA in the sandy soil and of up to 70 DAA in the clayey soil.

Thus, these results indicate that a single application of sulfentrazone can avoid weeds interference in cassava crops by the time corresponding to the critical period of

(A)

$\hat{y}=19.8628+0.2854$ Dose- 0.3878 DAA-0.0002Dose ${ }^{2}+0.003 D_{A A}{ }^{2} ; R^{2}=0.88^{\star *}$

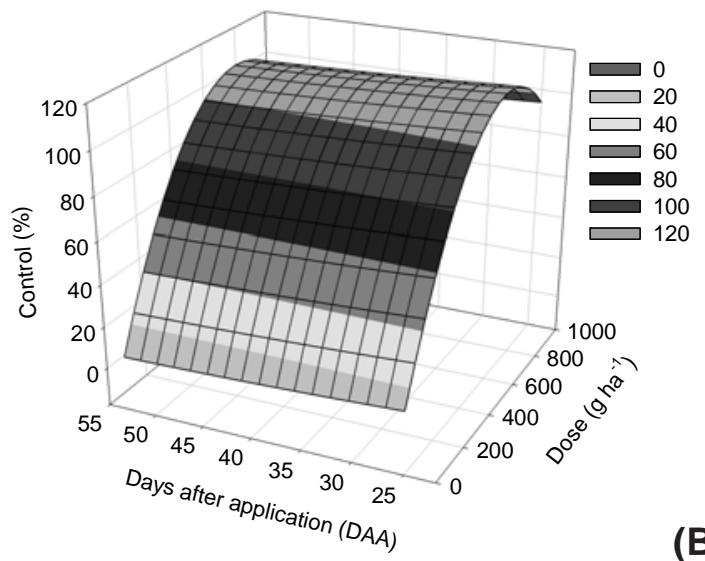

$\hat{y}=6.2584+0.289$ Dose +0.3518DAA-0.0002Dose $e^{2}-0.0057 D_{\text {DA }}{ }^{2} ; R^{2}=0.90^{* *}$

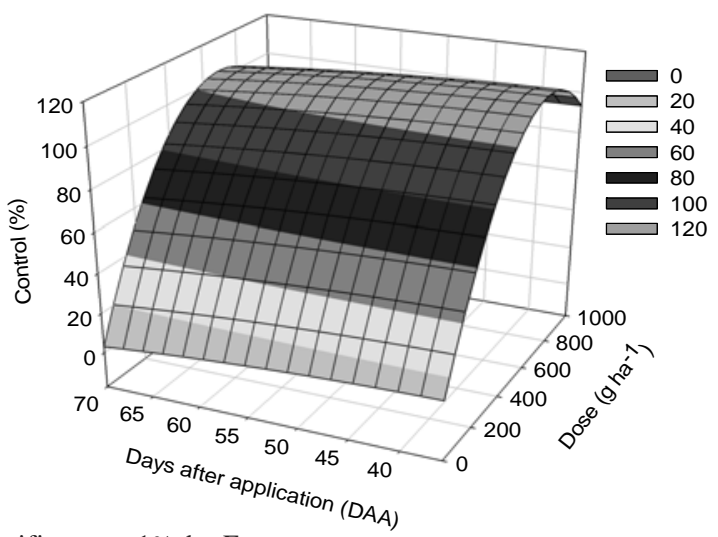

** significant at $1 \%$ by F-test.

Figure 2 - Percentage of weed control after applying sulfentrazone in sandy (A) and clayey (B) soils. 
interference, which can vary 25-77 days after planting (Alabi et al., 2004; Albuquerque et al., 2008; Biffe et al., 2010).

Sulfentrazone application in sandy soil crops has linearly reduced root production at a ratio of $0.0153 \mathrm{t} \mathrm{ha}^{-1}$ for each increment in grams of the active ingredient (Figure $3 \mathrm{~A}$ ).

The degree of weed interference on the crops was $58.3 \%$, being obtained by the difference in roots production between weeded and non-weeded controls. However, it is emphasized that the doses of 250, 500 and $750 \mathrm{~g} \mathrm{ha}^{-1}$ of sulfentrazone have provided superior performance compared to the nonweeded control production, around 54.3, 44.2 and $22.5 \%$, respectively.

In Figure 3B, the production means of cassava roots grown in clayey soil after application of sulfentrazone are presented. There was a similar behavior for applications in sandy soil. However, it can be seen that for each increase of grams of the active ingredient, a reduction in productivity of 0,0107 t ha $^{-1}$ occurred.

It should also be noticed that the yield obtained after the application of the highest dose of sulfentrazone was higher than that obtained by the non-weeded control (Figure 3B).

It is important to mention that sulfentrazone presents more adsorption on clayey soils with a large amount of organic matter due to the large specific surface and high retention and ion exchange capacities, compared to applications in sandy textured soils (Polubesova et al., 2003; Rossi et al., 2010). However, sulfentrazone physicochemical characteristics (solubility in water $=490 \mathrm{mg} \mathrm{L}^{-1}$ and the low values of Koc $=43$ and Kow $=1.48)$ (Rodrigues \& Almeida, 2011), indicate greater mobility of the active ingredient in the sandy soil profile, compared to clayey soils.

Comparing the angular coefficients of the equations of Figures $3 \mathrm{~A}$ and $\mathrm{B}$, it can be inferred that sulfentrazone productivity reduction rate in clayey soil was $30.1 \%$ lower than the rate for applications in sandy soil. However, it is emphasized that this fact does not prove this study hypothesis that
(A)

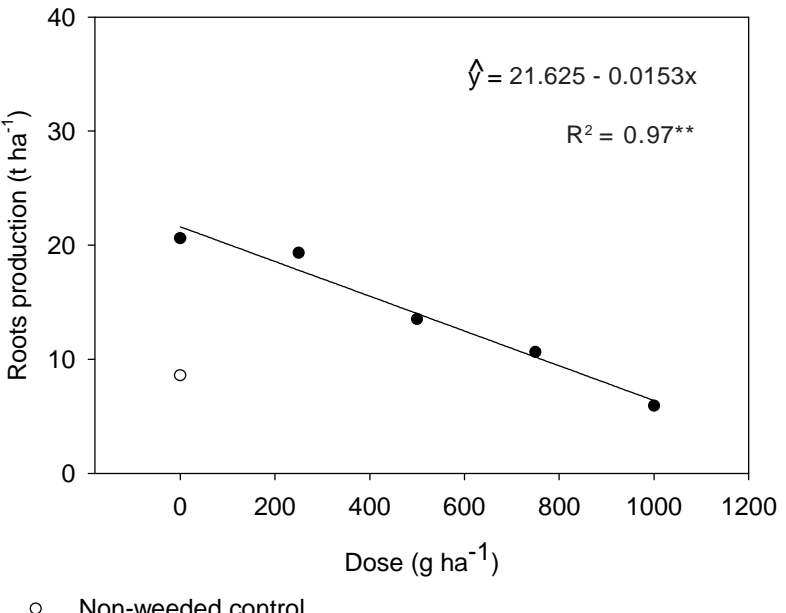

(B)

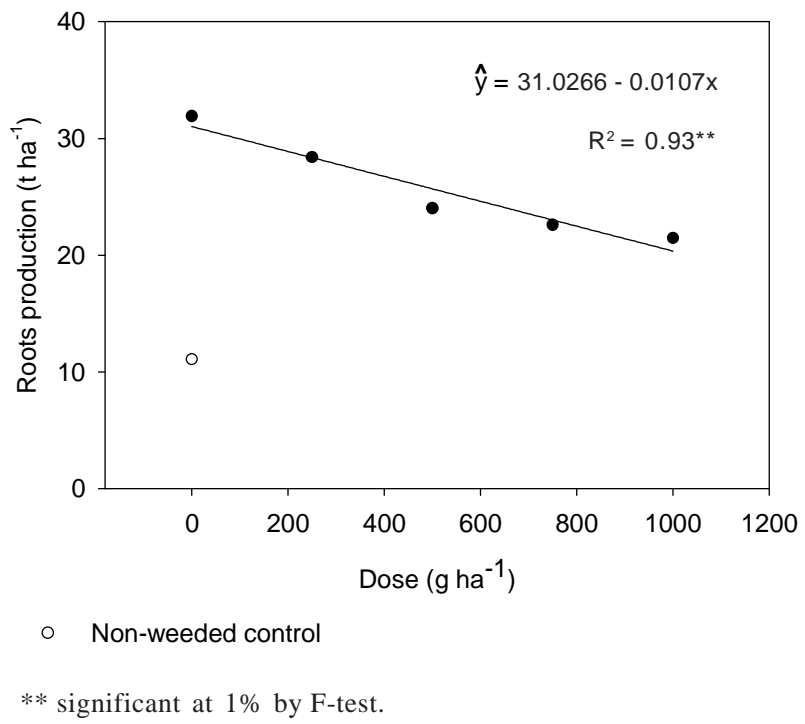

Figure 3 - Cassava plants roots production after applying sulfentrazone in sandy (A) and clayey (B) soils.

sulfentrazone selectivity may be dependent on the dose and the type of soil used for cassava cultivation, since sulfentrazone applications have reduced crop yield compared to the nonapplied control.

In general, this study results corroborate those obtained by Oliveira Jr. et al. (2001a), who have observed that sulfentrazone application (600 $\left.\mathrm{g} \mathrm{ha}^{-1}\right)$ in averaged textured dystrophic red latosol (70\% of sand) in the notillage system promotes $62.9 \%$ decreased productivity compared to non-weeded control and was not selective for cassava cultivar 
Espeto. However, they differ from those obtained by Scariot et al. (2013), who have observed that sulfentrazone (600 $\left.\mathrm{g} \mathrm{ha}^{-1}\right)$ and the mix of clomazone+sulfentrazone $\left(900+500 \mathrm{~g} \mathrm{ha}^{-1}\right)$ have not caused intoxication and have not reduced the production of Cascuda cassava roots in clayey soil $(55 \%$ of clay), being considered selective. However, the result obtained by Scariot et al. (2013) may indicate the existence of differential tolerance among cultivars to the application of sulfentrazone in clayey soil, and cultivar Cascuda was more tolerant than cultivar Baianinha used in the present study.

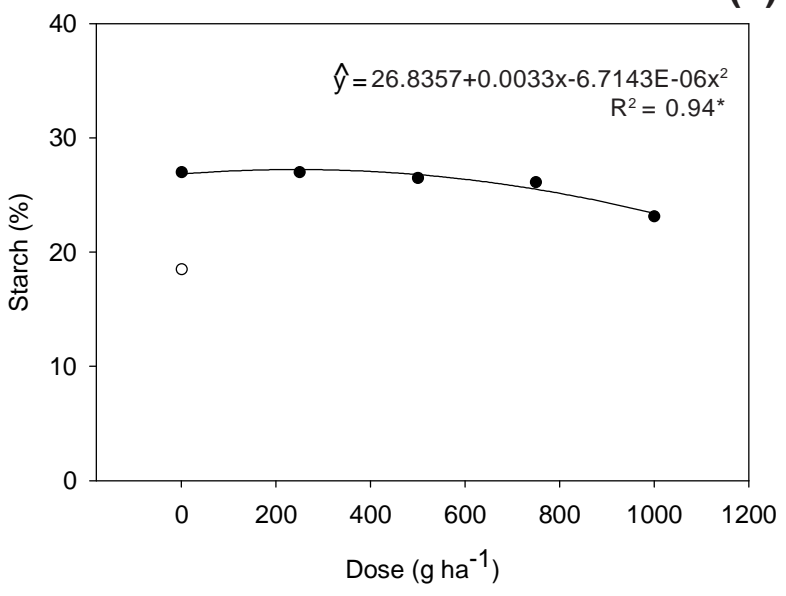

- Non-weeded control

(B)

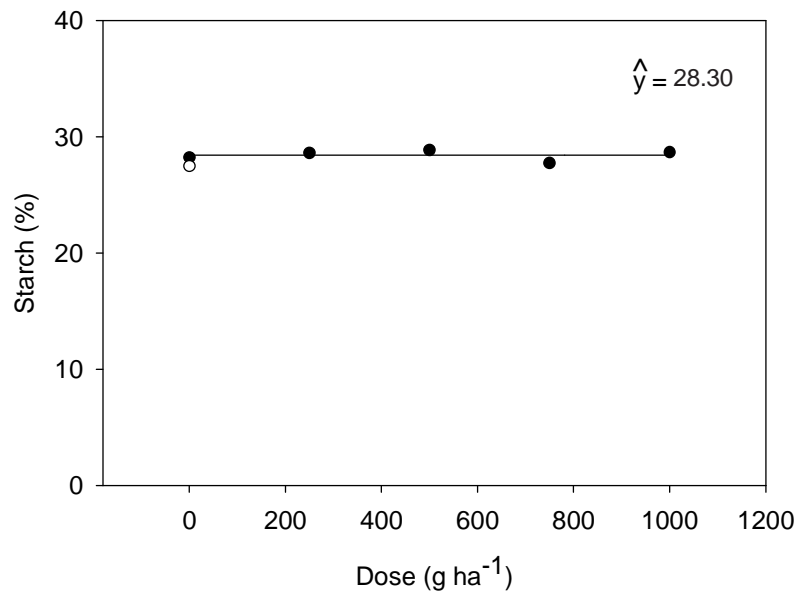

- Non-weeded control

* significant at $5 \%$ by F-test.

Figure 4 - Starch content in cassava plants roots after applying sulfentrazone in sandy (A) and clayey (B) soils.
Researchers Oliveira Jr et al. (2001b) and Silveira et al. (2013) have also found the occurrence of differential tolerance to herbicide in cassava cultivars. This fact indicates that the herbicides selectivity to the cassava crop may depend on the cultivar used.

The application of sulfentrazone in sandy soil has decreased the starch content in the roots from the dose of $242.7 \mathrm{~g} \mathrm{ha}^{-1}$; in herbicide doses of 500, 750 and $1,000 \mathrm{~g} \mathrm{ha}^{-1}$ the reductions were of $1.9,3.2$ and $14.4 \%$, respectively, in relation to the weed control (Figure 4A). However, the starch content in the roots of the non-weeded control plants was $31.5 \%$, lower than that obtained in the weeded control. In Figure 4B, sulfentrazone applications in clayey soil have not influenced root starch content: the average was $28.3 \%$ and there was virtually no difference between controls.

As sulfentrazone selectivity for cassava was observed Scariot et al. (2013), it is suggested that further studies are conducted for sulfentrazone dose adjustment and tank mixtures, especially in crops in clayey soil, to determine selectivity or tolerance of the main cultivars to the herbicide.

It is concluded that sulfentrazone was not selective for cassava crops grown in sandy and clayey soils used in this study. However, sulfentrazone was highly effective in controlling weeds in the soils above mentioned.

\section{LITERATURE CITED}

ALABI, B. S. et al. Manual control of Thorny Mimosa (Mimosa invisa) in Cassava (Manihot esculenta). Weed Technol., v. 18, n. 1, p. 77-82, 2004.

ALBURQUERQUE, J. A. A. et al. Interferência de plantas daninhas sobre a produtividade da mandioca (Manihot esculenta). Planta Daninha, v. 26, n. 2, p. 279-289, 2008.

AZEVÊDO, C. L. L. et al. Levantamento de plantas daninhas na cultura da mandioca, em um ecossistema semi-árido do Estado da Bahia. Magistra, v. 12, n. 1/2, p. 41-49, 2000.

BECKIE, H. J. Herbicide-resistant weeds: management tactics and practices. Weed Technol., v. 20, n. 3, p. 793-814, 2006. 
BECKIE, H. J.; REBOUD, X. selecting for weed resistance: herbicide rotation and mixture.

Weed Technol., v. 23, n. 3, p. 363-370, 2009.

BIFFE, D. F. et al. Avaliação de herbicidas para dois cultivares de mandioca. Planta Daninha, v. 28, n. 4, p. 807-816, 2010.

COSTA, N. V. et al. Seletividade de herbicidas aplicados com óleo mineral na cultura da mandioca ‘Cascuda'. R. Bras. Herb., v. 12, n. 3, p. 251-259, 2013.

CUENCA, M.A. G; MANDARINO, D. C. Aspectos agroeconômicos da cultura da mandioca: características e evolução da cultura no Estado do Sergipe entre 1990 e 2004. Aracaju: Embrapa, 2006. 21 p. (Documentos, 98).

EL-SHARKAWY, M.A. Cassava biology and physiology. Plant Molec. Biol., v. 53, n. 5, p. 481-501, 2004.

GROSSMANN, J.; FREITAS, A. C. Determinação do teor de matéria seca pelo peso específico em raízes de mandioca. R. Agron., v. 14, n. 160/162, p. 75-80, 1950.

\section{INSTITUTOBRASILEIRODE GEOGRAFIA E} ESTATÍSTICA-IBGE. Levantamento Sistemático da produção Agrícola: pesquisa mensal de previsão e acompanhamento das safras agrícolas no ano civil, janeiro de 2015, v. 29 n. 1, p. 1-83, 2015. Disponível em: shttp://www.google.com.br/\#q=Levantamento+ Sistemático+da+produção+Agrícola:+pesquisa+mensal+de+ previsão+e+acompanhamento+das+safras+agrícolas+no+ ano+civil+2015>. Acesso em: 19 mar. 2015.

JOHANNS, O.; CONTIERO, R. L. Efeitos de diferentes períodos de controle e convivência de plantas daninhas com a cultura da mandioca. R. Ci. Agron., v. 37, n. 3, p. 326-331, 2006.

OLIVEIRA JR., R. S. et al. Manejo químico de plantas daninhas em área de plantio direto de mandioca.

R. Bras. Herb., v. 2, n. 3, p. 99-106, 2001a.

OLIVEIRA JR., R. S. et al. Tolerance of five cassava (Manihot esculenta) cultivars to herbicides. Planta Daninha, v. 19, n. 1, p. 119-125, 2001 b.
PERESSIN, V.A.; CARVALHO, J. E. B. Manejo integrado de plantas daninhas em mandioca. In: CEREDA, M.P. (Org.). Cultura de Tuberosas Amiláceas Latino Americanas. São Paulo: Fundação Cargill, 2002. v. 2. p. 302-349.

POLUBESOVA, T. et al. Sulfentrazone adsorbed on micelle-montmorillonite complexes for slow release in soil. J. Agric. Food Chem., v. 51, n. 11, p. 410-3414, 2003.

RODRIGUES, B. N.; ALMEIDA, F. S. Guia de herbicidas. Londrina: IAPAR, 2011.697 p.

ROSSI, C. V. S. et al. Mobilidade do sulfentrazone no perfil de classes de solos. R. Bras. Herb., v. 4, n. 1, p. 65-77, 2010.

SCARIOT, C. A. et al. Seletividade e eficiência de herbicidas aplicados em pré-emergência na cultura da mandioca. Pesq.Agropec. Trop., v. 43, n. 3, p. 300-307, 2013.

SILVA, D. V. et al. Manejo de plantas daninhas na cultura da mandioca. Planta Daninha, v. 30, n. 4, p. 901-910, 2012.

SILVA, F. M. L. et al. Moléculas de herbicidas seletivos à cultura da mandioca. R Trópica: Ci. Agr. Biol., v. 3, n. 2, p. 61-72, 2009.

SILVEIRA, H. M. et al. Sensibilidade de cultivares de mandioca ao herbicida mesotrione. R. Bras. Herb., v. 11, n. 1, p. 24-31, 2012.

SILVEIRA, H. et al. Características fisiológicas de cultivares de mandioca após aplicação do mesotrione. Planta Daninha, v. 31, n. 2, p. 403-409, 2013.

SOCIEDADE BRASILEIRA DA CIÊNCIA DAS PLANTAS DANINHAS - SBCPD. Procedimentos para instalação, avaliação e análise de experimentos com herbicidas. Londrina: 1995. 42 p.

VENCILL, W. K. et al. Herbicide resistance: toward an understanding of resistance development and the impact of herbicide-resistant crops. Weed Sci., v. 60, p. 2-30, 2012. (Special Issue) 